\title{
Starting From a Ground Level: A Hope of Reconciliation in Lucy's Silence and Subjection in Disgrace
}

\author{
Xue Chen \\ School of Foreign Languages, Taishan University, Taian, Shandong, China
}

\begin{abstract}
This paper focuses on Lucy's double predicaments as a white woman in post-apartheid South Africa in J.M. Coetzee's novel Disgrace. As an heir of settler history and as the other to men in the patriarchal society, Lucy becomes a scapegoat of history and is raped by three black men. With a post-colonial interpretation of Lucy's rape, this paper interprets Lucy's silence about her rape and subjection to the blacks as her efforts to achieve a peaceful relationship with the blacks. Her determination to love the child bred in hatred by the black rapists shows a hope of reconciliation between whites and blacks through forgiveness and love.
\end{abstract}

Index Terms — predicaments, rape, silence, subjection, reconciliation

\section{INTRODUCTION}

J.M. Coetzee is a celebrated South African novelist, literary critic, and recipient of the 2003 Nobel Prize in Literature. Most of Coetzee's novels focus on his homeland both in and after apartheid era although many are ambiguous about the specific location and time due to the allegorical characteristic of his writing style. Disgrace (1999) as one of his few realism novels portrays the post-apartheid South Africa in the perspective of a fifty-two-year-old white literary professor. The novel is well received after its publication and wins Coetzee the Booker Prize in 1999. However, at the same time the novel has been criticized, especially by the South African critics, for racism due to its stereotyped description of the black rapist. Even the president Thabo Mbeki protested its description of South Africa as a violent country. Therefore, the rape event is not only a major event of the novel but also a critical focus. While most critics concentrate on the character Lurie as a representative of the whites in post-apartheid Africa, this paper centers on Lucy as a representative of the white female, and interprets Lucy's rape from a post-colonial perspective as an indispensable part to understand her later choice.

The first part of the paper illustrates Lucy's predicaments in post-apartheid South Africa from two aspects: her predicaments as a white descendant and as a woman. These predicaments finally lead to her rape. The second part analyzes Lucy's choice after her rape, which is found difficult to understand by Lurie and many readers as well. The key is Lucy's different understanding of her rape from her father. Therefore, this part analyzes rape from two aspects: rape as the blacks' revenge against the whites, and rape as a tool of oppression against the blacks. While the first aspect is easy to understand and is illustrated in the novel, the second one is implicit and crucial to interpret Lucy's choice of remaining silent about her rape. With an analysis of the complicated political significance of Lucy's rape, the third part further points out that Lucy's choice of silence about her rape and her subjection to Petrus mean her determination for a new start and a hopeful way out of the dilemma.

\section{LUCY's PREDICAMENTS IN POST-APARTHEID SOUTH AFRICA}

\section{A. Lucy's Predicament as an Heir of the Settler History}

Lurie describes Lucy as a "sturdy young settler"(Coetzee, 1999, p.61) and "a boervrou"(Coetzee, 1999, p.60). According to him, it is history that plays a major role in Lucy's choice of giving up the city life to be a frontier farmer, and this history is the colonial past. The word "boer," which specifically refers to the Dutch descendant in South Africa, actually means peasant in Dutch. The Dutch people have been known as the best farmer in Europe. This farming tradition to a large extent leads to a fierce competition between the Afrikaners and the indigenous blacks over the rare arable land back to the colonial time. Salem, the location of Lucy's small holding, used to be a major site of historical conflict over the land control between white colonists and the native. Therefore, this location suggests the "inescapable presentness of this past" (Cornwell, 2003, p.44) in Lucy's relationship with the native blacks and further justifies the historical significance of Lucy as a landowner and Petrus's craving for Lucy's land in post-apartheid South Africa.

Yet Lucy is different from her white predecessors in the colonial and apartheid time. She regards Petrus as her independent co-proprietor, and her rage at the use of the word "boy," a negative reference to the blacks by the whites, suggests her opposition to the oppression of blacks imposed by whites. Compared to Lurie, Lucy is more ready to adapt to the redistribution of the land and power in this new South Africa and to establish a friendly relationship with the local. 
However, she is still an outsider for the local blacks due to her birthmark representing a history of violence and dispossession against the blacks. On one hand, Lucy is self-conscious of her alienation from the local. When Lurie first goes to the local market with Lucy, he finds "a show of bonhomie from which Lucy, to his relief, holds herself apart"(Coetzee, 1999, p.71). Besides, the historical colonial heritage of the alarm system against the black - the gun and dogs Lucy keeps, suggests a potential hostility from the black Lucy defending herself against. On the other hand, the native blacks cannot truly accept Lucy as one of them. Petrus once called Lucy his benefactor. It is ironic for this address represents an unequal power relationship in the old time and then suggests Petrus's definition of Lucy as essentially the same as her white predecessors. Under their superficially peaceful and friendly relationship are Petrus's dissatisfaction with his inferior status as Lucy's dog-man and gardener, his ambition for Lucy's land which he believes ought to belong to their black, and his rooted definition of Lucy as the Other to his people. This unstable relationship Lucy attempts to build is so delicate that any incident will turn it into confrontation and even hatred against her.

Despite the fact that Lucy is a frontier farmer of the new breed and different from her white predecessors, the inevitable part of her self constructed by the colonial and apartheid past of violence and dispossession fails Lucy to involve herself with as well as to be accepted by the native, and it even puts her in a state of danger at this darker time of the country when the law is dysfunctional, the social order is broken down, and the violence is rampant.

\section{B. Lucy's Predicament as the Other to Men}

Since Lurie is taken as the "focalizer" of the novel, readers actually view Lucy through Lurie's "gaze," which is a symbol of power. It is noticeable that some description of Lucy by Lurie impresses readers not as a father observing a daughter but more like a man gazing at a woman. This feeling is especially strong when Lurie focuses on Lucy's physical characteristics: ample hips and breasts, and good and shapely feet. According to Laura Mulvey (2001), through this "male gaze" woman becomes a spectacle and is objectified. This objectification of woman is also shown when Lurie puts woman into the same category of things that must go into circulation like his stolen cars and shoes after the violent attack. It suggests a patriarchal ideology which sees woman as the subordinate and part of men's property. Therefore, he reveals a sense of pity for Lucy's lesbian identity. "Attractive, he is thinking, yet lost to men. Need he reproach himself or would it have worked out like that any way?" (Coetzee, 1999, p.76). As a man who claims that a woman has a duty to share her beauty with the world (men especially), Lurie takes her daughter's lesbian identity as a loss of men. The word "reproach" reflects Lurie's opposition to lesbians who violate the social norms dominated by men, and his inner desire to subject Lucy to these norms. From Lucy's final explosion after her rape we know that this domination has always existed since her youth. "You behave as if everything I do is part the story of your life. You are the main character, I am a minor character...."(Coetzee, 1999, p.198). But Lucy has managed to seek an independent life by choosing a totally different life from his father to establish her own narrative of her life story. And it is not only Lurie's shadow but that of the whole patriarchal society that Lucy wants to get out of. According to radicalfeminism, a lesbian is a woman fighting for her wholeness and freedom against patriarchal oppression. Therefore, Lucy's lesbian identity symbolizes her challenge against the female role constructed by the male- dominated society and her "refusal of the economic, ideological, and political power of a man"(Wittig, 1981, p.1639).

Unfortunately, however, in spite of Lucy's attempts to establish her solid and independent existence on the farm, she still cannot get out of a sociohistorical and colonial structure in which women are "ordinarily institutionalized as male property" (Nixon, 1997, p.77) for it is shared by all men, either white or black. Petrus regards woman as goods he needs to pay for. "Now, today, the man does not pay for the woman. I pay"(Coetzee, 1999, p.130). Therefore he tells Lurie a woman here must marry because an unmarried woman is like property without protection, and therefore is exposed to violent capture. White women used to be an exclusive exchange between white men and therefore were inaccessible property to the black male in the colonial and apartheid time. But in post-apartheid time, white women are involved into the circulation system accessible to the black male, in which women are put together with goods like cars and shoes. Therefore, as an unmarried woman living alone on the farm, Lucy falls to be a fair game, the property without owner and thereby available to anyone. This predicament along with her identity as an heir of the settler history finally leads to her devastating rape.

\section{SilENCE AND SUBJECTION AS A HopefUl WAY OUT}

\section{A. Rape as Revenge against Whites}

What shocks Lucy most is the personal hatred of the three black rapists she does not even notice before. Lurie explains this hatred as historical instead of purely personal. "It was history speaking through them" (Coetzee, 1999, p.156). In a colonial context, rape is no less violence against men than against women. As it is mentioned in the first part, since women are seen as male property, rape, therefore, is defined as "a war of dispossession.... a male war"(Nixon 1997, p.77). When it occurs in the colonial and apartheid time, rape becomes a tool of oppression and exploitation because the whites are always the part who dominates this war. While the white men encroach upon the black women without being punished, any contact beyond a master-salve relationship between the white women and the black men is forbidden. In the novel, Lurie, a hangover of the past, has a desire for exotic women and at the same time is irresponsible towards them. "He had thought of it (love affair) as a quick affair - quickly in, quickly out" (Coetzee, 1999, p.27). This way of cleansing himself out after initiating an affair suggests a colonial history in which white men 
violate black women with impunity. In the novel, Lucy describes the three black intruders as "rapists first and foremost." She says, "Stealing things is just incidental... I think they do rape"(Coetzee, 1999, p.158). The verb "do" illustrates that their rape is organized, prepared and this is not the first time they do it. In other words, they rape Lucy not upon desire but on purpose. Their cruel slaughter of the dogs which have been "bred to snarl at the mere smell of a black man" (Coetzee, 1999, p.110) since the colonial time and their hatred against Lucy suggest that they rape her to take revenge for the colonial and apartheid past of dispossession and oppression and how their black women were used by the whites.

If the white male colonize the black male's sexuality by raping their women, then the blacks deconstruct the white male's privilege in the same way. Since white women are a sign of the privilege system which denies the black men, the rape of white women hence functions as an indirect attack against the white men. While agreeing that rape is a property crime of men against men, Susan Brownmiller(1975) further points out the significance of white woman as exclusive to white men in the colonial rule: "The purity of white womanhood, enforced by social mores as compelling as the whip, was as critical a touchstone of the white masculinity as the system of slaveholding itself'(p.217). Thus by raping white women, the black men challenge the white men's authority and superior status. Lurie regards Lucy's rape as his disgrace mainly because Lucy's rape makes Lurie conscious of his powerlessness against blacks and further strengthens his feeling of emasculation in post-apartheid time. Besides, the purity of white women is crucial to guarantee a pure lineage. After knowing Lucy's pregnancy by the rapists, he is shaken: "They were not raping, they were mating"(Coetzee, 1999, p.199), and it means that "his line is going to run out"(Coetzee, 1999, p.199). Since the pure lineage has played an important role in justifying the white privilege, Lucy's pregnancy is a blow to Lurie who clings fast to the past. In this male war of dispossession and revenge, white woman are put in a dilemma: "Women find themselves unenviably cast as a first-class icons but second-class citizens. They are denied the arms to defend themselves while are weighted down with symbolic responsibilities as guarantors of homeland, ethos, and lineage"(Nixon, 1997, p.77).

Lucy finds herself in a similar dilemma though she lives in a different time, a even darker time. Neither laws nor the old alarm system of guns and dogs can protect her from this violence. Not to mention the powerless white men represented by his father and her decaying neighbor Ettinger. Lucy then becomes the scapegoat of the past wrong.

\section{B. Rape as Oppression against Blacks}

It is necessary to point out that while rape as a tool of colonial oppression mentioned above refers to the rape of black women by white men, this part focuses on how rape is used to oppress black men. When collecting her essay materials about the sexual violence of the white male against black women during the slavery time in the South of America, Susan Brownmiller(1975) is given a lot of newspapers reporting the rape of white women by the black men and told that “[to] black people, rape has meant the lynching of the black man"(p.212). It suggests a racialized conception of rape as black on white constructed by the whites. Rape becomes a political act. White men refuse to admit that their sexual violence against black women is rape, and at the same time they highlight the image of black men as violent rapist to prove the blacks are savage and violent and to justify the whites' superiority over blacks. It is the same in South Africa where rape was widely used to legalize oppression against the blacks in the colonial and apartheid time. It is noticeable that media reports about sexual violence against white women increased obviously in the transition period of 1990s in South Africa. These sensational reports actually reflect the whites' anxieties about their status and power after the abolition of apartheid. Since Lucy's rape by three black men conforms to the prejudiced stereotype of the black rapist, the novel Disgrace has been criticized as a racist book and the very reflection of white paranoia in post-apartheid South Africa. But this paper would prefer to see the novel as a self-introspection of the whites and as Lucy Valerie Graham(2003) says, “a subversion of 'black peril' narrative”(p.433).

Lucy and her father fall into unsettled disputes after the attack due to their different interpretations of her rape. In her letter to her father, Lucy writes: "You do not see this, and I do not know what more I can do to make you see. It is as if you have chosen deliberately to sit in a corner where the rays of the sun do not shine"(Coetzee, 1999, p.161). This reveals that Lurie fails and even refuses to see the rape as Lucy views it. In Lurie's opinion, Lucy's rape is simply a voluntary act of racial revenge, and her rapists want to enslave her to avenge the humiliating and suffering slavery history. By denying her father's expression of "slavery" and replace it with "subjection" and "subjugation," Lucy points out rape as first and foremost is a gender crime of man against woman. While Lurie has always believed that he and Lucy are on the same side for he regards Lucy's rape as an interracial crime of blacks against whites, Lucy puts him in doubt when she classifies him into the same group with her black rapists. "When it comes to men and sex, David, nothing surprises me anymore. Maybe, for men, hating the woman makes sex more exciting. You are a man, you ought to know. When you have sex with someone strange - when you trap her, hold her down, get her under you, put all your weight on her-isn't it a bit like killing?" (Coetzee, 1999, p.159). Lucy describes her feeling of being raped by using the personal pronoun of "you" and "her" instead of "they" and "I." This makes roles of victimizer and victim changeable. On one hand, it means that the victimizer can be any male regardless of color, and accordingly the victim can be both white and black women. On the other hand, this "you" and "her" suggests a parallel between Lucy's rape and another major plot of the novel - Lurie's "love affair" with Melanie. Here quotation marks are used because this is just what Lurie would like to call it. With a close reading of the description of Lurie's sex with Melanie, readers will 
find expressions similar to Lucy's description of her own rape. "Not rape, not quiet that, but undesired nevertheless, undesired to the core. As though she had decided to go slack, die within herself for the duration, like a rabbit when the jaws of the fox close on its neck"(Coetzee, 1999, p.25). The metaphor of Lurie and Melanie as fox and rabbit compares their sexual relationship to that of predator and prey. A similar hunting scene is also depicted by Lucy with a series of verbs: trap, hold down, and get under. Besides, the description of Melanie as a rabbit desperately waiting to be bitten by the fox illustrates that she goes through the same feeling of sex as killing as Lucy. Lurie's emphasis of his act as "not rape" sounds like self-conviction, and even self-deception. He justifies himself as "a servant of Eros" and his act as on desire out of his control. This he believes makes his action noble and different from rape. According to the novel, Melanie has Chinese cheekbones, dark eyes and black hair, and Lurie once describes her as "the dark one"(Coetzee, 1999, p.164). Although this is not enough to establish her as a black, she is definitely a non-white. This adds more political significance to her sexual relationship with Lurie for it suggests a colonial past when the white male justify their sexual violence against black women as natural and are thereby free of impunity. Fixed-minded and unwilling of bending to the new change, Lurie refuses to call his rape as rape due to his racist ideology. But Melanie's unwillingness and his forcible intrusion show his action as essentially the same as what the three black men do to Lucy. Thus by paralleling Lucy's rape and Lurie's sexual violence against Melanie, the novel deconstructs the white myth of the whites as superior. In this way, the novel is illustrated not as a racist one, but one to subvert the racial stereotype against blacks.

\section{Silence and Subjection as a Hopeful Way out}

Rape is a horrible crime against woman, and it is especially devastating for a lesbian. But Lucy refuses to lay charges against her rapists. "What happened to me is a purely private matter. In another time, in another place it might be held to be a public matter. But in this place, at this time, it is not. It is my business, mine alone"(Coetzee, 1999, p.112). As it is mentioned above, rape has been a tool of oppression in a colonial discourse. It is never a private matter of the female victim but a public trial against all the blacks. Therefore, rape of white women by the black men would always receive an extensive media coverage, which consolidates the image of the violent and uncivilized blacks and justifies the whites' repulsion and segregation against blacks. But the fact often ignored is that most rapes in South Africa are intraracial and that the rape of black women rarely draws much attention. The circulation of horrible stories about black rapists strengthens national prejudice against blacks. By refusing to speak about her rape, Lucy refuses to participate in the racial construction of rape. She knows that if she shows herself as a victim, she will at the same time help to justify the racial prejudice against blacks. Therefore, she remains silent to reject the violence of representation and a circle of revenge.

While Disgrace describes the white dilemma in post-apartheid South Africa, at the same time it exhibits three choices of the whites in their predicament: extinction, self-exile or adaption. Lucy's old neighbor Ettinger represents the fewer whites still struggling to defend their land as well as their status in this new world. He turns his house to fortress and guards himself with guns. He is the only one left in Africa while his children have gone back to Europe. Even if Ettinger survives from attack, he will one day die of old age with no descendants to inherit his land, leaving no trace on this land. In contrast to this is Petrus's prosperous family with two wives and the coming baby. Disappointed with this new country, Lurie suggests they leave. However, Lucy chooses to stay and to adapt. She accepts her rapists as tax collectors of the past colonial and apartheid debt and her rape as a deserved retribution. She contributes her land to Petrus for his protection, changes from a hopeful frontier farmer to a bywoner, and decides to give birth to the baby by her rapists. All these show Lucy's determination to establish a new relationship with the blacks in this new South Africa. "To start at ground level. With nothing. Not with nothing but. No cars, no weapons, no property, no rights, no dignity" (Coetzee, 1999, p.205). It can be seen from the novel that after the abolition of apartheid the whites still lead a more abundant and advanced life than most blacks, at least for the time being. Although Petrus is portrayed as a success arising from a tenant to a landowner, his initial relationship with Lucy as her employed assistant is a reflection of the relationship between most blacks and whites. While the whites were deprived of privilege in post-apartheid South Africa, a practical equal relationship between the whites and the blacks was not achieved at then. Lucy is more ready than her father to adapt to the re-distribution of land and power, and to get along with the native in a friendly way. But the land, the gun and the dogs Lucy keeps are all heritage of the past colonial and apartheid history, the "but" after "with nothing." Therefore, her generosity to Petrus is seen as benefaction but not help. "To start at ground level" means to totally give up the white privilege, which is represented in the novel by the land, the guns and guarding dogs, and the pure lineage.

Besides giving up her dignity as a white descendant, Lucy also sacrifices her dignity as an independent woman to survive on this land. She subjects herself to be Petrus's third wife, and decides to give birth to the child by her rapists. As she says, "Love will grow" and she believes she will love the child, which is symbolic of a fusion of blacks and whites. While the child is bred in hatred, it can be cultivated in love, and so will the new relationship between whites and blacks in post-apartheid South Africa. At the end of the novel, a pastoral scene is described that Lucy alone works on the land, being pregnant. After an experience of decay and death, Lucy survives and "looks, suddenly, the picture of health" (Coetzee, 1999, p.218). Woman, who is said in the novel to be "surprisingly forgiving" (Coetzee, 1999, p.69) and adaptable, is shown to "bear" a hope of reconciliation.

\section{CONCLUSION}


While most critics analyze the white dilemma in the post-apartheid South Africa by focusing on the white male character Lurie, this paper tries to show the worse environment against the white female in the new South Africa with an analysis of the character Lucy. Although Lucy loves the land and wants to live in a friendly way with the native blacks, her identity as an heir of the settler history puts her in a hostile confrontation with the local. Moreover, Lucy's attempts to establish an independent life free of patriarchal domination are threatened due to the patriarchal construction of women as men's property shared by all men, either white or black. As a result, Lucy's identity as a white descendant and woman available leads to her gang rape, and Lucy becomes the scapegoat of the past wrong. Different from her father Lurie, who sees this rape as racial revenge, Lucy believes that it has no essential distinction from any rape as a crime of men against women. By refusing to justify and represent herself as a victim to the public, Lucy rejects to represent the black men as violent rapist and to participate in the rape narrative constructed by the whites to oppress the blacks. Instead of running away, she chooses to stay and to accept the redistribution of land as well as power in the new South Africa, gives up her dignity and starts a new life and a new relationship with the native. Lucy's determination to love her child bred in hatred and the peaceful and beautiful scene of Lucy working in the farm at the end of the novel seem to convey Coetzee's thinking about a promising solution, not only for Lucy but for the whole nation, to the racial problems, and that is forgiveness and love.

\section{REFERENCES}

[1] Brownmiller, S. (1975). Against our will: Men, women and rape. New York: Simon and Schuster.

[2] Coetzee, J. (2000). Disgrace. London: Vintage Books.

[3] Cornwell, G.(2003). Disgraceland: History and the humanities in frontier country. English in Africa, 2, 43-68.

[4] Mulvey, L.(2001). Visual pleasure and narrative cinema. In V.B. Leitch (Ed.), The Norton Anthology of Theory and Criticism. New York: W. W. Norton \& Co., 2184-2188.

[5] Nixon, R. (1997). Of Balkans and bantustans: Ethnic cleansing and the crisis in national legitimation. In A. McClintock, A. Mufti\& E. Shohat (Eds.), Dangerous Liaisons: Gender, Nation, \& Postcolonial Perspectives. Minneapolis: University of Minnesota Press, 69-88.

[6] Valerie, L. G. (2003). Reading the unspeakable: Rape in J.M. Coetzee's Disgrace. Journal of South African Studies, 29, 433-444.

[7] Wittig, M. (2007) One is not born a woman. In D. H. Richter (Ed.), The Critical Tradition: Classic Texts and Contemporary Trends. New York: Queen's College of the City University of New York, 1637-1643.

Xue Chen was born in Jinan, China in 1991. She received her master's degree in English literature from Xiamen University, China in 2016.

She is currently a teaching assistant in the School of Foreign Languages, Taian University, Taian, China. Her research interests include British and American literature. 